\title{
Epidemiological evaluation of non-melanoma skin cancer according to body distribution
}

\author{
Non-melanom deri kanserinin vücut dağılımına göre epidemiyolojik değerlendirmesi
}

\section{Soysal Baș, ๑ Șafak Çakır, ๑ Yunus Ertaș, ๑ Fatih Irmak, ๑ Ayșin Karasoy Yeșilada}

University of Health Sciences Turkey, Șișli Hamidiye Etfal Training and Research Hospital, Clinic of Plastic, Reconstructive and Aesthetic

Surgery, İstanbul, Turkey

\begin{abstract}
Background and Design: Non-melanoma skin cancer is one of the most common types of cancer and epidemiological data are important for public awareness. In this study, we aimed to reveal an epidemiological data according to tumor location.

Materials and Methods: Four hundred sixty-four patients with non-melanocytic skin cancer who had surgical operation between March 2014 and March 2019 were included. Patients were retrospectively evaluated in regards to theirage, sex, diagnosis, histopathological type, tumor location and surgical treatment.

Results: In this study 464 patients and 547 lesions were evaluated. Two hundred and seventy-one of the patients were male (58.5\%) and 193 were female (41.5\%). The patients ranged in age from 13 to 100 years (mean: $66.3 \pm 13.45) .69 .8 \%(n=321)$ of the patients were operated for basal cell carcinoma, $28.2 \%(n=131)$ of squamous cell carcinoma and $1.9 \%(n=9)$ of them were operated for basosquamous cell carcinoma. The rate of basal cell carcinoma and squamous cell carcinoma in women was 3, this ratio was found to be 2.3 in males. 450 (82.2\%) of the tumors were in the head and neck and $61(11.1 \%)$ in the trunk, $18(3.2 \%)$ in the upper extremity and $16(2.9 \%)$ in the lower extremity. The recurrence rate was $5.6 \%$ in all lesions. In addition, recurrence rates were found to be $4.9 \%$ for basal cell carcinoma and $7.6 \%$ for squamous cell carcinoma in the head and neck region.

Conclusion: Being conducted in İstanbul, Turkey, this study researched nonmelanoma skin cancers which are predominantly located in the head and neck region. Turkey is a country with a young population. However, the young population is particularly engaged in industrial and agricultural fields. Considering the cumulative effects of the sun, this data shows that measures to protect the head and neck region from the sun should be increased.
\end{abstract}

Keywords: Skin cancer, basal cell cancer, squamous cell carcinoma

\section{Öz}

Amaç: Non-melanom deri kanseri en sık görülen kanser çeşitlerinden olup; epidemiyolojik verilerin ortaya konması, halkın bilinçlendirilmesi açısından önemlidir. Bu çalışmada tümör lokalizasyonuna göre epidemiyolojik verilerin ortaya konması amaçlanmışır.

Gereç ve Yöntem: Bu çalışmaya, Mart 2014 ile Mart 2019 tarihleri arasında non-melanositik deri kanseri tanısı ile cerrahi tedavi uygulanan 464 hasta dahil edilmişsir. Hastalar yaş, cinsiyet, tanı, histopatolojik tipi, tümör lokalizasyonu ve uygulanan cerrahi tedavi açısından retrospektif olarak değerlendirilmiştir.

Bulgular: Çalışmada 464 hasta ve 547 lezyon değerlendirilmiştir. Çalışmaya dahil edilen hastaların 271'i erkek (\%58,5), 193'ü kadındı (\%41,5)

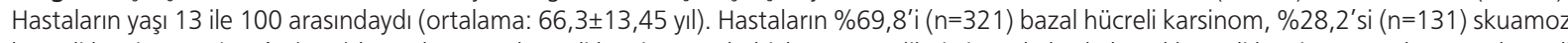
hücreli karsinom, \%1,9'u (n=9) bazoskuamoz hücreli karsinom sebebiyle opere edilmişti. Kadınlarda bazal hücreli karsinom ve skuamoz hücreli karsinom oranı 3 iken erkeklerde bu oran 2,3 olarak saptandı. Tümörlerin 450'si $(\% 82,2)$ baş-boyu bölgesinde, 61'i $(\% 11,1)$ gövdede; 18'i $(\% 3,2)$ üst ekstremitede ve 16 'sı $(\% 2,9)$ alt ekstremitede yerleşimli idi. Tüm lezyonlarda nüks oranı \%5,6 saptanmıștı. Ek olarak, baş-boyun bölgesinde nüks oranı bazal hücreli karsinom için \%4,9 ve skuamoz hücreli karsinom için \%7,6 olarak saptanmışır.

Sonuç: İstanbul'da yapılan bu çalışmada melanom dışı deri kanserleri ağırlıkı olarak baş ve boyun bölgesinde yer almaktadır. Türkiye genç

Address for Correspondence/Yazışma Adresi: Soysal Baș MD, University of Health Sciences Turkey, Şişli Hamidiye Etfal Training and Research Hospital, Clinic of Plastic, Reconstructive and Aesthetic Surgery, istanbul, Turkey Phone: +90 5368982117 E-mail: soysalbas@gmail.com

Received/Geliş Tarihi: 09.11.2019 Accepted/Kabul Tarihi: 26.02.2020 ORCID: orcid.org/0000-0002-4657-1613 
nüfusa sahip bir ülkedir. Bununla birlikte, genç nüfus özellikle endüstriyel ve tarımsal işlerle uğraşmaktadır. Güneşin kümülatif etkileri göz önüne alındığında, bu veriler baş ve boyun bölgesini güneşten koruma önlemlerinin artırılması gerektiğini göstermektedir.

Anahtar Kelimeler: Deri kanseri, bazal hücreli kanser, skuamöz hücreli kanser

\section{Introduction}

Non-melanoma skin cancers (NMSC) are one of the most common types of cancer in the United States, with the majority being basal cell carcinoma (BCC) and squamous cell carcinoma (SCC) ${ }^{1}$. The incidence of BCC is 127.9 per 100.000 for males and 104.8 for females; SCC is 25.2 for males and 8.6 for females. The lifelong risk of a Caucasian individual for BCC is $28-33 \%$, it is $7-11 \%$ for $\mathrm{SCC}^{2}$.

The most important risk factor for NMSC is ultraviolet (UV) radiation exposure. Over the years, ozone layer thinning, tanning became popular, changing the style of clothing, such as the prolongation of exposure to the sun ${ }^{3}$. The NMSC rate is high due to UV exposure in areas close to the equator ${ }^{4}$. Genetic diseases such as Xeroderma pigmentosum, Gorlin syndrome, albinism, as well as light skin and colored eyes (especially Fitzpatrick type 1, 2), premalignant skin lesions, immunosuppression, chronic irritation, ionizing radiation and chemical exposure are among the other risk factors ${ }^{5,6}$.

Mortality rate of NMSC is low. Mortality rates for BCC and SCC were $1.15 \%$ and $2.17 \%$, respectively ${ }^{7}$. However, it can cause morbidities such as deformity in the head and neck region, limited mouth opening, speech and eating problems, scleral show, ectropion, visual field effect and orbital exenteration. While BCC is usually presented with slow growth pattern and local invasion, SCC may be more aggressive and metastatic as well as local invasion. Since BCC metastasis rate is 1-2 per 14.000.000, it is accepted that it does not perform metastasis. SCC metastasis rate ranged from $0.1 \%$ to $9.9 \%{ }^{8}$.

The aim of this study was to evaluate the epidemiological data of the patients in Istanbul who underwent surgical treatment between 20142019 with the diagnosis of NMSC according to tumor location.

\section{Materials and Methods}

As this study was designed as a retrospective and single-center study, because of ethics committee approval was not obtained. The study adhered to the principles of the Helsinki Declaration and written informed consent was obtained from the patients for the use of the data.

Four hundred sixty-four patients with non-melanocytic skin cancer who underwent surgical treatment between March 2014 and March 2019 were included in this study. Patients with distant metastasis were considered inoperable and were not included in the study. Patients were retrospectively evaluated for age, sex, diagnosis, histopathological type, tumor location and surgical treatment.

In all patients, treatment algorithm was determined according to diagnostic incisional biopsy results. Imaging method was not required for tumor metastasis screening in patients with BCC. Head and neck, thorax, abdominal computer tomography and regional lymph node ultrasonography were performed for metastasis screening in patients with basosquamous cancer (BSC) and SCC. Excision was performed by placing a $10 \mathrm{~mm}$ surgical margin for BSC and SCC and $5 \mathrm{~mm}$ surgical margin for BCC. After surgical excision of the tumor at the appropriate surgical margin and depth, primary repair, full thickness skin graft (FTSG), split thickness skin graft (STSG), local or free flap reconstruction were performed. In the presence of pathological lymph nodes demonstrated by clinical and imaging methods, regional lymph node dissection was added to the treatment.

\section{Statistical Analysis}

SPSS version 23.0 (SPSS Inc, Chicago, IL) was used for statistical analysis. Descriptive statistics; the number and percentage for genders, histopatological types and subtypes, reconstructive options, anatomic locations and recurrence rates. Mean and standard deviation for ages were given.

\section{Results}

Four hundred sixty-four patients and 547 lesions were evaluated. Of the patients included in the study, 271 were male (58.5\%) and 193 were female $(41.5 \%)$. The patients ranged in age from 13 to 100 years (mean: $66.3 \pm 13.45) .69 .8 \%(n=321)$ of the patients were operated for BCC, $28.2 \%(n=131)$ for SCC and $1.9 \%(n=9)$ for BSC. There were 40 BCCs and 13 SCCs in patients with two lesions. There were 12 BCCs and 2 SCCs in patients with three lesions. There were $166 \mathrm{BCC}$, 54 SCC, 2 BSC in women and 222 BCC, 96 SCC, 7 BSC in men. BCC and SCC ratio in women 3; this ratio was found to be 2.3 in men. 450 $(82.2 \%)$ of the tumors were in the head and neck and $61(11.1 \%)$ in the trunk, $18(3.2 \%)$ in the upper extremity and $16(2.9 \%)$ in the lower extremity. The mean age of the patients with head and neck tumors was $66.7 \pm 12.8,64.3 \pm 13.1$ for trunk, $71.8 \pm 15.2$ for upper extremities and $49.8 \pm 21.7$ for lower extremities. BCC was observed in the head and neck, trunk and extremities while squamous cell carcinoma in the head and neck, upper extremity, lower extremity and trunk respectively by frequency. In head and neck, $72.2 \%$ ( $n=325)$ of the cases were BCC, $26.2 \%(n=118)$ of SCC, $1.5 \%(n=7)$ of BSC. $93.4 \%(n=57)$ of the cases were BCC in the trunk, $6.5 \%(n=4)$ of SCC. $16.6 \%(n=3)$ of the cases were BCC in the upper extremity, $83.3 \%(n=15)$ of SCC. $16.6 \%(n=3)$ of the cases were BCC in the lower extremities, $72.2 \%(n=13)$ of SCC, $11.1 \%(n=2)$ of BSC (Table 1).

$53.8 \%$ of BCC cases were nodular, $22.6 \%$ superficial, $18.5 \%$ infiltrative, $4.8 \%$ morpheiform, adenoid, micronodular histopathologic subtype. $62 \%$ of SCC cases were well differentiated, $22.6 \%$ were moderately differentiated, $10.6 \%$ were poorly differentiated, $4.6 \%$ were in situ. The most common BCC subtype was found nodular in the head and neck region superficial in the trunk, and the infiltrative type in the upper and lower extremities. In SCC patients, lesions in the head, neck, trunk and upper extremities were often well differentiated, while the lower extremity was the most frequently poorly differentiated (Table 2). After tumor excision, 139 lesions (25.2\%) were underwent primary repair, 196 lesions (37.5\%) TKDG or KKDG, 202 lesions (38.1\%) local flaps, and 10 lesions (1.8\%) free flaps. Lymph node metastasis was detected in $25(19 \%)$ of SCC patients and 1 (17.2\%) of BSC patients. 
Neck dissection was performed in 20 patients, inguinal dissection in 3 and axillary dissection in 3. Primary lesions of the patients who had lymph node metastasis were located in the lower lip in 13 patients, in the ear in 2, and in the upper lip, nose, cheek and forehead in 1. Regional lymph node metastasis was detected in 6 patients with hand or foot lesions (Table 3). The follow-up period was 6 months to 5 years (mean: 36.2 months).

The recurrence rate of all NMSCs was 5.6\%. Recurrence rates for head and neck region were $4.9 \%$ for BCC and $7.6 \%$ for SCC. For upper extremity $5.2 \%$ for BCC, $6.6 \%$ for SCC and $13.3 \%$ for SCC in lower extremity. The detailed anatomical distribution and recurrence rates of NMSCs are shown in Figure 1. In terms of morbidity, unilateral orbital exenteration in three patients, total ear amputation in two, partial ear amputation in three, ectropion and scleral show in two, partial facial nerve paralysis in two patients were observed. Amputation was applied to the fingers in two patients and toes in one. Hypertrophic scar was found in the trunk in two patients and in the lower extremity in one.

\section{Discussion}

UV radiation exposure is the most important cause of skin cancer, especially $\mathrm{SCC}^{9}$. In particular, a 10\% reduction in the ozone layer, which is protective against short wave UV-radiation (UVB), is expected to increase skin cancers by $40 \%{ }^{10}$. In 1988, the Ozone Trend Panel reported that the ozone layer was reduced by $2 \%$ over the last 20 years ${ }^{11}$. Another evidence showing the relationship between sun rays and skin cancer is that skin cancer is more common in areas of the body exposed to sunlight ${ }^{12}$.

NMSC is more common in advanced age. Ceylan et al. ${ }^{5}$ reported that the mean age at diagnosis was 62.8 , while the mean age was 66.3 in this study. The mean age was found to be 39.2 in SCC cases with lower extremity and lower than the general body distribution. This is due to the fact that Marjolin's ulcer, which develops from a chronic wound floor, is seen at a younger age and is often diagnosed with $\mathrm{SCC}^{13}$.

In a study of 12956 NMSCs by Katalinic et al. ${ }^{14}$, the female to male

Table 1. Demographic data of patients by location

\begin{tabular}{|c|c|c|c|c|c|c|}
\hline & & Head and neck & Trunk & Upper extremity & Lower extremity & Total \\
\hline \multirow{3}{*}{ Gender, n (\%) } & Female & $165(85.4)$ & $12(6.2)$ & $10(5.1)$ & $6(3.1)$ & $193(100)$ \\
\hline & Male & $233(85.9)$ & $23(8.4)$ & $6(2.2)$ & $9(3.3)$ & $271(100)$ \\
\hline & Total & 398 (85.7) & $35(7.5)$ & $16(3.4)$ & $15(3.2)$ & $464(100)$ \\
\hline \multirow{4}{*}{ Lession, n (\%) } & $\mathrm{BCC}$ & 325 (83.7) & $57(14.6)$ & $3(0.7)$ & $3(0.7)$ & $388(100)$ \\
\hline & SCC & $118(78.6)$ & $4(2.6)$ & $15(10)$ & $13(8.6)$ & $150(100)$ \\
\hline & BSC & $7(77.7)$ & - & - & $2(22.2)$ & $9(100)$ \\
\hline & Total & $450(82.2)$ & $61(11.1)$ & $18(3.2)$ & $18(2.9)$ & 547 \\
\hline \multirow{4}{*}{ Age (mean $\pm S D)$} & $\mathrm{BCC}$ & $66.1 \pm 12.5$ & $64.3 \pm 13.4$ & $82 \pm 0$ & $76 \pm 15.55$ & $66.1 \pm 12.67$ \\
\hline & SCC & $67.8 \pm 13.5$ & $67.5 \pm 12.0$ & $69.8 \pm 15.9$ & $39.2 \pm 12.9$ & $66.2 \pm 15.1$ \\
\hline & BSC & $72.3 \pm 12.5$ & - & - & $72 \pm 0$ & $73.44 \pm 12.1$ \\
\hline & Total & $66.7 \pm 12.8$ & $64,3 \pm 13.1$ & $71.8 \pm 15.2$ & $49.8 \pm 21.7$ & $66.3 \pm 13.45$ \\
\hline
\end{tabular}

Table 2. Histopathological results of patients by location

\begin{tabular}{|c|c|c|c|c|c|c|}
\hline & \multicolumn{5}{|l|}{ Location } \\
\hline & & Head and neck & Trunk (n) & Upper extremity (n) & Lower extremity (n) & Total (n) (\%) \\
\hline \multirow{7}{*}{$\mathrm{BCC}$} & Nod & 194 & 14 & - & 1 & $209(53.8)$ \\
\hline & $\operatorname{lnf}$ & 53 & 15 & 2 & 2 & $72(18.5)$ \\
\hline & Supfic & 61 & 27 & - & - & $88(22.6)$ \\
\hline & Aden & 7 & 1 & 1 & - & $9(2.3)$ \\
\hline & Micnod & 7 & - & - & - & $7(1.8)$ \\
\hline & Morph & 3 & - & - & - & $3(0.7)$ \\
\hline & Total & 325 & 57 & 3 & 3 & $388(100)$ \\
\hline \multirow{5}{*}{ SCC } & WD & 80 & 2 & 8 & 3 & $93(62)$ \\
\hline & MD & 27 & 2 & 1 & 4 & $34(22.6)$ \\
\hline & PD & 8 & - & 3 & 5 & $16(10.6)$ \\
\hline & IS & 3 & - & 3 & 1 & $7(4.6)$ \\
\hline & Total & 118 & 4 & 15 & 13 & $150(100)$ \\
\hline
\end{tabular}




\section{Table 3. Reconstruction options of patients by location}

\begin{tabular}{|c|c|c|c|c|c|c|}
\hline & & \multicolumn{5}{|l|}{ Location } \\
\hline & & Head and neck, n (\%) & Trunk, n (\%) & Upper extremity, n (\%) & Lower extremity, n (\%) & Total, n (\%) \\
\hline \multirow{3}{*}{ Primarily repaired } & $\mathrm{BCC}$ & $94(81)$ & $19(16.3)$ & $2(1.7)$ & $1(0.8)$ & $116(100)$ \\
\hline & SCC & $18(90)$ & - & $2(10)$ & - & $20(100)$ \\
\hline & BSC & $3(100)$ & - & - & - & $3(100)$ \\
\hline \multirow{3}{*}{ Skin graft } & $\mathrm{BCC}$ & $119(80.4)$ & $21(11.9)$ & - & $2(1.4)$ & $142(100)$ \\
\hline & SCC & $32(65.3)$ & $2(4)$ & $8(16.3)$ & $7(14.2)$ & $49(100)$ \\
\hline & BSC & $3(60)$ & - & - & $2(40)$ & $5(100)$ \\
\hline \multirow{3}{*}{ Local flap } & $\mathrm{BCC}$ & $110(85.9)$ & $17(813.2)$ & $1(0.7)$ & - & $128(100)$ \\
\hline & SCC & $62(84.9)$ & $2(2.7)$ & $5(6.8)$ & $7(9.5)$ & $73(100)$ \\
\hline & BSC & $1(100)$ & - & - & - & $1(100)$ \\
\hline \multirow{2}{*}{ Free flap } & $\mathrm{BCC}$ & $5(100)$ & - & - & - & $5(100)$ \\
\hline & SCC & $5(100)$ & - & - & - & $5(100)$ \\
\hline $\begin{array}{l}\text { Lymph node } \\
\text { dissection }\end{array}$ & SCC & $20(76.9)$ & - & $3(11.5)$ & $3(11.5)$ & $26(100)$ \\
\hline
\end{tabular}

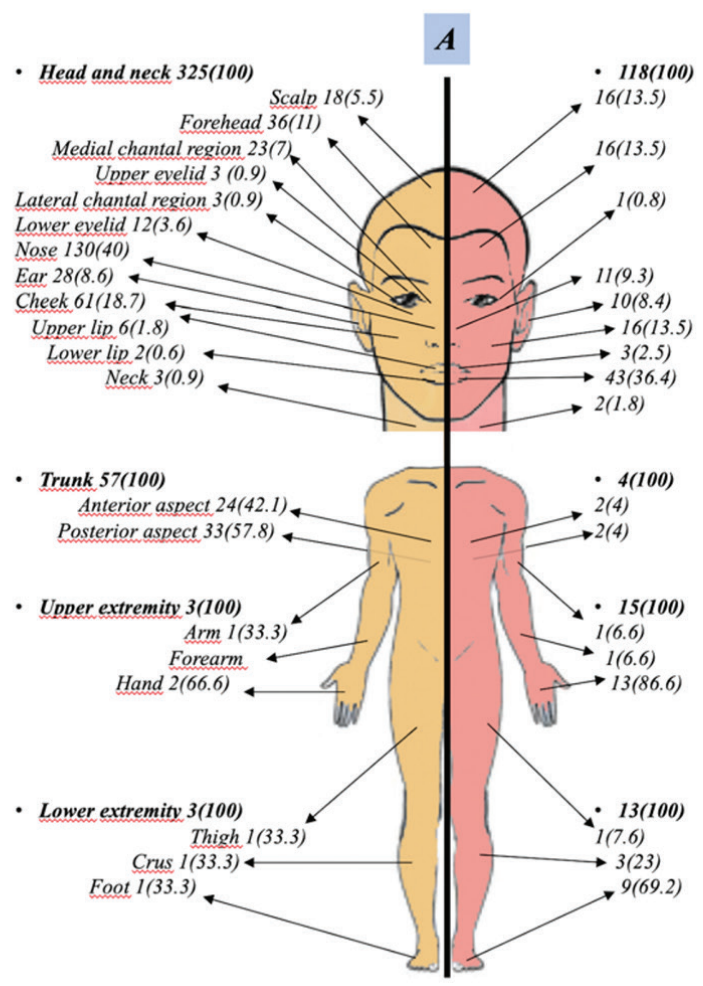

Figure 1. Anatomical location and recurrence rates of tumor masses BCC: Basal cell carcinoma, SCC: Squamous cell carcinoma

ratio was 0.72 , and 0.78 for $B C C$ and 0.46 for SCC. In this study, the ratio was $0.69,0.52$ in BCC, and 0.56 in SCC. In the epidemiological study of Leiter and Garbe ${ }^{15}$, the BCC and SCC ratio was approximately 2, while it was 2.5 in this study. In addition, the ratio of BCC and SCC in women is 3; males were found to be 2.3. In Turkey, the reason why SCC occurs more in men than in women, it is attributable to the fact that women are less involved in working life, the proportion of men in

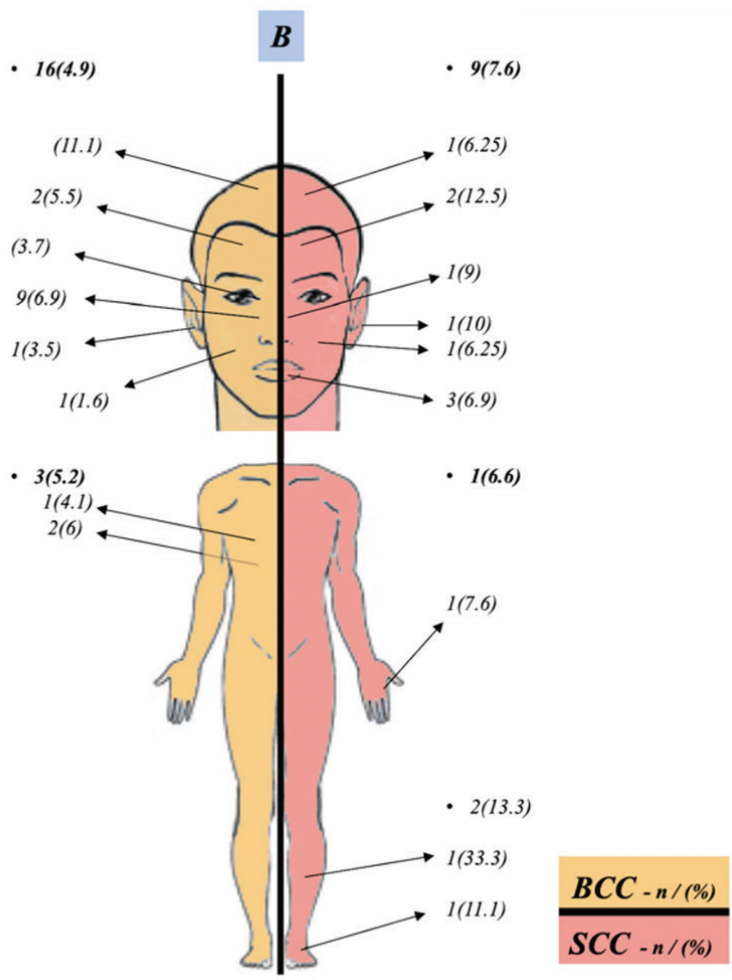

outdoor work is higher, and women are exposed to less sunlight due to clothing habits. Although NMSCs are more common in men, they have regional and sociological differences. Emiroğlu and Cengiz ${ }^{16}$ reported that NMSCs are more common in females than in males in Kütahya region where female agricultural workers are frequent.

In a study involving 2374 patients in Australia in 2017, the body distribution of BCC was observed in the head and neck (40.2\%), trunk 
(33.9\%), upper (13.7\%) and lower extremities (12.1\%), respectively. SCC was observed in upper extremity $(34.9 \%)$, head and neck (33.9\%), lower extremity $(23.4 \%)$ and trunk (8.4\%), respectively ${ }^{17}$. In this study, both BCC (83.7\%) and SCC (78.6\%) were mostly seen in the head and neck region. The second most common SCC was seen in the upper extremity, followed by the lower extremity and trunk. In the study conducted by Ceylan et al. ${ }^{5}$ in Izmir in 2003, the lesions were predominantly located in the head and neck. The lower incidence of SCC in the body compared to BCC is due to cumulative and chronic high-dose solar exposure and occupational exposure of SCC. BCC is due to intermittent or infrequent high dose UV radiation and genetic interactions ${ }^{17,18}$. Apart from sunlight, the GSTM1 null CYP1A1 genotype has been associated with multiple localized BCCs ${ }^{19}$.

Findık et al..$^{20}$ evaluated 400 patients in 2019 in Turkey and reported that BCC was seen, in order of frequency, in the nose, periorbital region and scalp while SCC was seen in the lower lip, periorbital region and ears. In this study, BCC was most commonly seen in the nose $(40 \%)$ in the head and neck region, followed by cheeks (18.7\%), forehead $(11 \%)$ and ears (8.6\%). SCC was seen in lower lip (36.4\%), scalp (13.5\%), forehead (13.5\%) and cheeks (13.5\%), respectively. BCC was seen on the back of the trunk, the anterior aspect of the trunk in order of frequency other than the head and neck. SCC except of head and neck was most commonly seen in the hands, followed by the feet. Richmond-Sinclair et al. ${ }^{21}$ Reported similar anatomical distribution for BCC in 2009 and Christenson et al. ${ }^{22}$ for SCC in 2003. The prevalence of SCC in the hands compared to BCC is explained by the epidermis location of the cells that turn into cancer ${ }^{23}$. Basal cells are located deep in the epidermis, squamous cells are more superficial. In the dorsum of the hand, the BCC frequency is less due to the fact that deeper located basal cells are more protected against UV rays than superficial cells. In addition, SCC is seen more frequently in lower lip compared to BCC is explained by smoking habit ${ }^{24}$.

Histopathological subtypes of BCC were the most common nodular subtype followed by superficial and infiltrative. While nodular BCC predominance was present in the head and neck region, superficial type BCC was common in trunk. Nodular BCC histopathologic subtype is more common after chronic sunlight exposure, whereas superficial BCC has been shown to develop as a result of intermitant sunlight exposure ${ }^{25}$. The lower exposure of the trunk to the head and neck region explains the histopathological subtype difference. In addition, it is predicted that genetic changes may affect histopathological subtypes and DNA damage increases the tendency to morpheiform and infiltrative BCC, although not fully proven ${ }^{26,27}$. Dogan ${ }^{28}$ reported that in his study in Turkey, BCC developed in indoor workers exposed to intermittent sun at an earlier age, while outdoor workers exposed to chronic sun developed in more aggressive subtypes. In addition, the majority of SCC cases were well differentiated. Well-differentiated SCCs are often caused by actinic keratosis due to sun damage. Poorly differentiated lesions occur in lesions caused by radiation damage, chronic irritation or burn scar and have a higher metastasis rate ${ }^{29}$. In this study, the rate of poorly differentiated lesions in the extremities increases while the rate of well-differentiated lesions is higher in lesions originating from sun-exposed areas.

In the treatment of low-risk lesions, cryotherapy, laser therapy and destructive treatments with electrocautery and immunotherapy for $\mathrm{BCC}$ are among the options. Mohs surgery is performed safely in order to obtain high aesthetic results with safe surgical margin especially in the head and neck region ${ }^{30-32}$. In recent years, similar recurrence and aesthetic results have been reported with brachytherapy and mohs surgery in lesions smaller than $2 \mathrm{~cm}^{33}$. Surgical treatment is prominent in high tumor burden and high-risk lesions. According to the National Comprehensive Cancer Network Surgical Excision Margin Guidelines, 4 $\mathrm{mm}$ surgical margin is recommended for low-risk BCC, 4-6 $\mathrm{mm}$ for SCC, and $1 \mathrm{~cm}$ for high-risk BCC and SCC $^{34}$

In surgical treatment, especially lesions smaller than $1-2 \mathrm{~cm}$ can be primarily repaired. The most important factor in primary repair is skin elasticity. In this study, primary repair was performed in 115 patients in the head and neck region, 19 in the trunk and 5 in the extremities. Skin grafts and flaps are preferred for lesions that cannot be repaired primary. In facial reconstruction, the donor site is often chosen for skin grafts, preauricular, postauricular and supraclavicular areas due to similar pigmentation. The upper eyelid can be grafted from the opposite upper eyelid. FTSGs are often used to avoid loss of pigmentation and to prevent skin contraction. STSG is preferred for large defects. Reconstruction was performed with skin graft in 154 patients in the head and neck region, 23 in the trunk and 19 in the extremities. Aesthetically, more satisfactory results are obtained with local flaps than skin grafts. It provides repair with similar tissues. Reconstruction with flap is preferred in the presence of bone without periosteum, tendon without paratenon and cartilage without perichondrium. Local flaps are especially preferred in the nose, lower eyelid, lips and cheeks. Reconstruction with local flap was preferred in

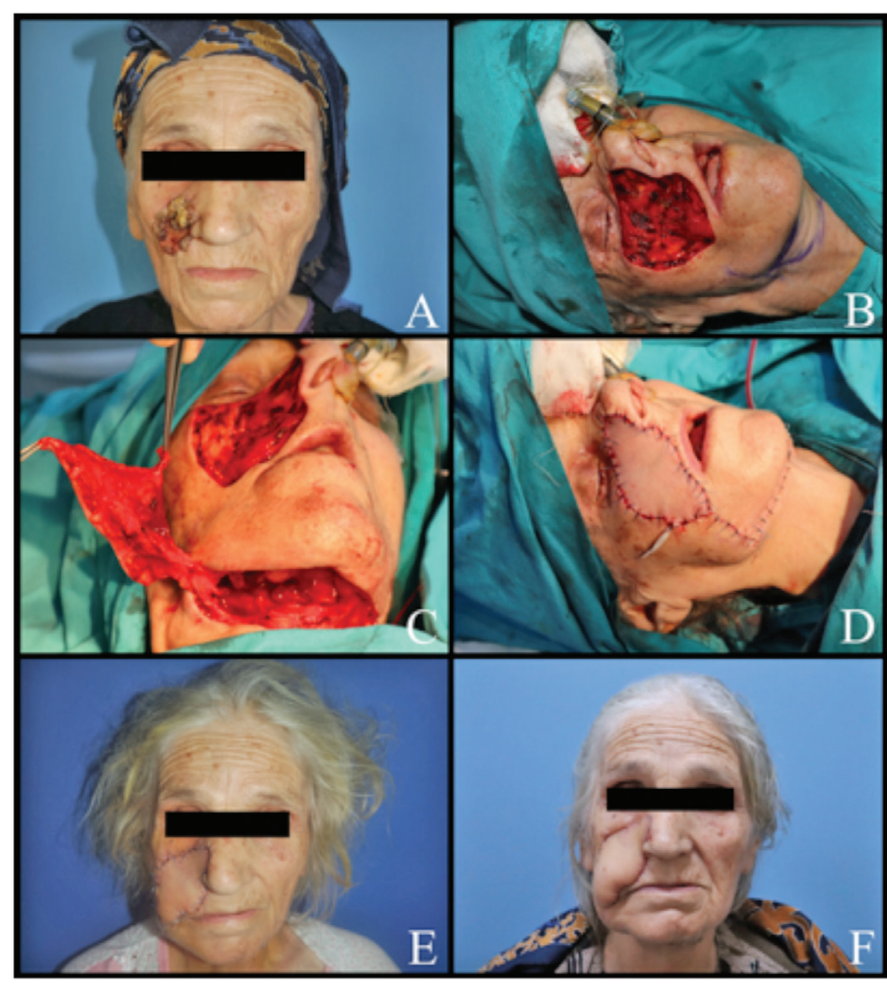

Figure 2. An 82-year-old female patient was planned for surgery for squamous cell carcinoma of the right cheek. A) Preoperative image. B) Defect area after peroperative tumor excision. C) Submental artery flap. D) Reconstruction of the defect area with flap. E) Postoperative third day view of the patient. F) Postoperative third week view of the patient 
173 patients in the head and neck region (Figure 2), 19 in the trunk and 13 in the extremities. Free flaps are preferred for the presence of defects that cannot be closed with local flaps and the need for threedimensional reconstruction. Five SCC and 5 BCC patients underwent free flap reconstruction after excision in the head and neck region (Figure 3).

Chren et al. ${ }^{35}$ reported that the recurrence rate after 309 NMSCs surgery was $4.5 \%$ and 9 of the lesions were BCC (5 lesions in the head and neck, 4 in the trunk) and 5 were SCC (3 lesions in the head neck and 2 in the trunk). In this study, the recurrence rate was $5.6 \%$. Recurrence rates for head and neck region were $4.9 \%$ for BCC and $7.6 \%$ for SCC. $5.2 \%$ for BCC in the trunk, $6.6 \%$ for SCC in the upper extremity and $13.3 \%$ for SCC in the lower extremity. Recurrence rate increases as the differentiation of SCC lesions decreases ${ }^{36}$. Although there is not enough number of patients to evaluate the extremities, most of the SCC lesions located in the lower extremities are poorly differentiated in this study.

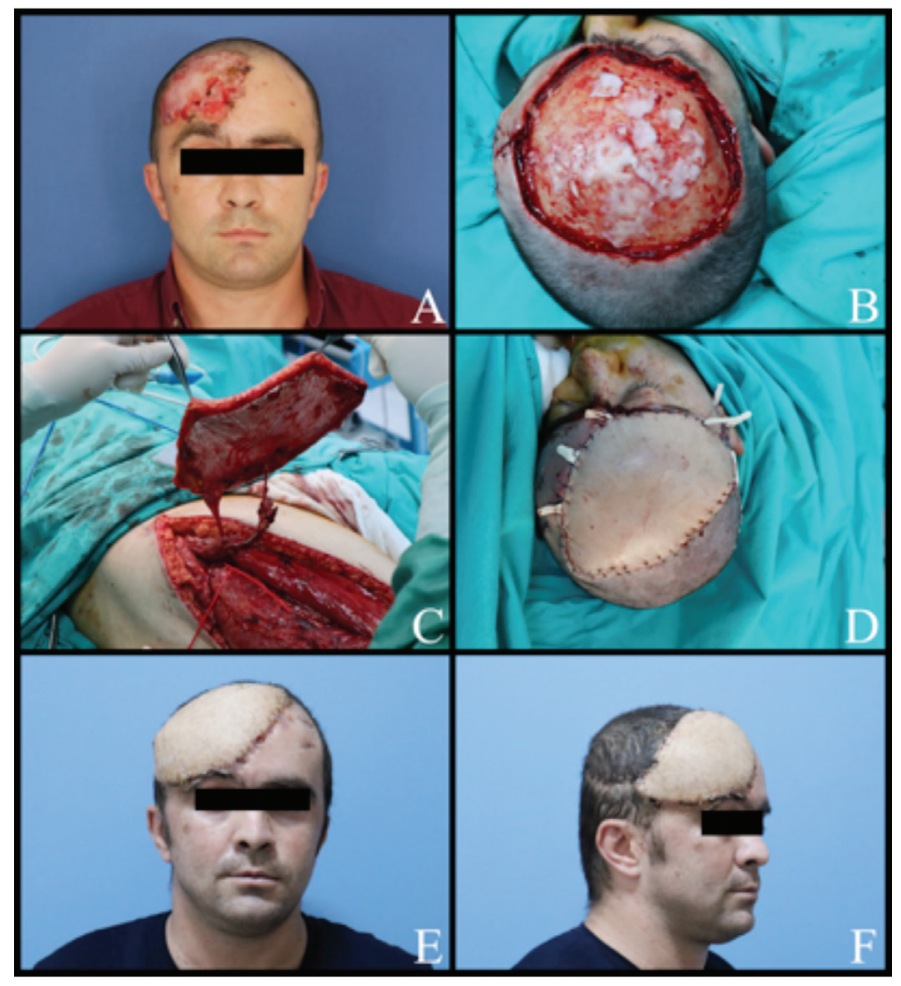

Figure 3. A) Preoperative image of a 23-year-old male patient planned for operation due to giant basal cell cancer in the right frontaparieral region. B) Image after peroperative tumor excision. C) Free anterolateral thigh flap. D) Image after peroperative flap adaptation. E) Postoperative third week anterior view. F) Postoperative third week oblique image

\section{Study Limitations}

The most important limitation of this study is its retrospective nature. In addition, the data consists of patient medical records.

\section{Conclusions}

The introduction of epidemiological data in NMSCs is important for raising awareness of patients and taking preventive measures. İstanbul is a cosmopolitan city that can reflect the whole country. In this study conducted in Istanbul, it was observed that NMSCs were predominantly located in the head and neck region and the morbidities frequently occurred in the head and neck region. Turkey is a country with a young population. However, the young population is particularly engaged in industrial and agricultural affairs. Considering the cumulative effects of the sun, this data shows that measures to protect the head and neck region from the sun should be increased.

\section{Ethics}

Ethics Committee Approval: As this study was designed as a retrospective and single-center study, because of ethics committee approval was not obtained.

Informed Consent: The study adhered to the principles of the Helsinki Declaration and written informed consent was obtained from the patients for the use of the data.

Peer-review: Externally peer-reviewed.

\section{Authorship Contributions}

Concept: S.B., A.K.Y., Design: S.B., F.I., A.K.Y., Data Collection or Processing: S.B., Ş.Ç., Y.E., Analysis or Interpretation: S.B., F.I., A.K.Y., Literature Search: S.B., Ş.Ç., Writing: S.B., Ş.Ç.

Conflict of Interest: No conflict of interest was declared by the authors.

Financial Disclosure: The authors declared that this study received no financial support.

\section{References}

1. Mendez BM, Thornton JF: Current basal and squamous cell skin cancer management. Plast Reconstr Surg 2018;142:373-87.

2. Diepgen $\mathrm{TL}$, Mahler $\mathrm{V}$ : The epidemiology of skin cancer. $\mathrm{Br} J$ Dermatol 2002;146:1-6.

3. Armstrong BK, Kricker A: The epidemiology of UV induced skin cancer. J Photochem Photobiol B 2001;63:8-18.

4. Giles GG, Marks R, Foley P: Incidence of non-melanocytic skin cancer treated in Australia. Br Med J (Clin Res Ed) 1988;296:13-7.

5. Ceylan C, Oztürk G, Alper S: Non-melanoma skin cancers between the years of 1990 and 1999 in Izmir, Turkey: Demographic and Clinicopathological Characteristics. J Dermatol 2003;30:123-31.

6. Zink A: Trends in the treatment and prevention of keratinocyte carcinoma (non-melanoma skin cancer). Curr Opin Pharmacol 2019;46:19-23.

7. Barton V, Armeson K, Hampras S, et al: Nonmelanoma skin cancer and risk of all-cause and cancer-related mortality: a systematic review. Arch Dermatol Res 2017;309:243-51

8. Didona D, Paolino G, Bottoni U, Cantisani C: Non melanoma skin cancer pathogenesis overview. Biomedicines 2018;6:6.

9. Apalla Z, Calzavara-Pinton $P_{1}$ Lallas $A$, et al: Histopathological study of perilesional skin in patients diagnosed with nonmelanoma skin cancer. Clin Exp Dermatol 2016;41:21-5.

10. Oikarinen A, Raitio A: Melanoma and other skin cancers in circumpolar areas. Int J Circumpolar Health 2000;59:52-6.

11. Kripke ML: Impact of ozone depletion on skin cancers. J Dermatol Surg Oncol 1988;14:853-7

12. Buettner PG, Raasch BA: Incidence rates of skin cancer in Townsville, Australia. Int J Cancer 1998;78:587-93.

13. Karasoy Yesilada A, Zeynep Sevim K, Özgur Sucu D, et al: Marjolin ulcer: clinical experience with 34 patients over 15 years. J Cutan Med Surg 2013;17:404-9.

14. Katalinic A, Kunze $U$, Schäfer T: Epidemiology of cutaneous melanoma and non-melanoma skin cancer in Schleswig-Holstein, Germany: incidence clinical subtypes, tumour stages and localization (epidemiology of skin cancer). Br J Dermatol 2003;149:1200-6. 
15. Leiter U, Garbe C: Epidemiology of melanoma and nonmelanoma skin cancer-the role of sunlight. Sunlight, vitamin D and skin cancer: 1st ed. New York. Springer; 2008. p. 89-103.

16. Emiroğlu N, Cengiz FP: Retrospective analysis of non-melanoma skin cancer in Kütahya Tavşanlı Region. Turkiye Klinikleri J Dermatol 2015;25:39-44.

17. Subramaniam P, Olsen CM, Thompson BS, et al: Anatomical distributions of basal cell carcinoma and squamous cell carcinoma in a population-based study in Queensland, Australia. JAMA dermatol 2017;153:175-82.

18. Kricker A, Armstrong BK, English DR, Heenan PJ: Does intermittent sun exposure cause basal cell carcinoma? a case-control study in Western Australia. Int J Cancer 1995;60:489-94.

19. Lear JT, Smith AG, Bowers B, et al: Truncal tumor site is associated with high risk of multiple basal cell carcinoma and is influenced by glutathione S-transferase, GSTT1, and cytochrome P450, CYP1A1 genotypes, and their interaction. J Invest Dermatol 1997;108:519-22.

20. Fındık S, Uyanık O, Altuntaş M, Altuntaş Z: Epidemiological and localization characteristics of non-melanoma skin cancers: Retrospective analysis of 400 cases. Turk J Plast Surg 2019;27:19-22.

21. Richmond-Sinclair NM, Pandeya N, Ware RS, et al: Incidence of basal cell carcinoma multiplicity and detailed anatomic distribution: longitudinal study of an Australian population. J Invest Dermatol 2009;129:323-8.

22. Christenson LJ, Borrowman TA, Vachon CM, et al: Incidence of basal cell and squamous cell carcinomas in a population younger than 40 years. JAMA 2005;294:681-90.

23. Tilli CMLJ, Van Steensel MAM, Krekels GAM, Neumann HAM, Ramaekers FCS: Molecular aetiology and pathogenesis of basal cell carcinoma. $\mathrm{Br} \mathrm{J}$ Dermatol 2005; 152:1108-24.

24. Nasser N, Nasser Filho N, Lehmkuhl RL: Squamous cell cancer-31-year epidemiological study in a city of south Brazil. An Bras Dermatol 2015;90:216.

25. Betti R, Radaelli G, Bombonato C, Crosti C, Cerri A, Menni S: Anatomic location of basal cell carcinomas may favor certain histologic subtypes. J Cutan Med Surg 2010;14:298-302.
26. Yu M, Zloty D, Cowan B, et al: Superficial, nodular, and morpheiform basalcell carcinomas exhibit distinct gene expression profiles. J Invest Dermato 2008;128:1797-805.

27. Dicker T, Siller G, Saunders N: Molecular and cellular biology of basal cell carcinoma. Australas J Dermatol 2002;43:241-6.

28. Dogan G. Basal cell carcinoma in outdoor versus indoor workers in Turkey. Int J Dermatol 2007;46:43-6.

29. Cassarino DS, Derienzo DP, Barr RJ: Cutaneous squamous cell carcinoma: a comprehensive clinicopathologic classification: part two. J Cutan Pathol 2006:33:261-79.

30. Kauvar AN, Cronin Jr T, Roenigk R, Hruza G, Bennett R, American society for dermatologic surgery: consensus for nonmelanoma skin cancer treatment: basal cell carcinoma, including a cost analysis of treatment methods. Dermatol Surg 2015;41:550-71.

31. Kauvar AN, Arpey CJ, Hruza G, Olbricht SM, Bennett R, Mahmoud BH: Consensus for nonmelanoma skin cancer treatment, part II: squamous cell carcinoma, including a cost analysis of treatment methods. Dermatol Surg 2015;41:1214-40.

32. Elçin G, Özer S, Gököz Ö, Yücel ÖT, Özaygen GE, Akan T: Micrographic surgey for the treatment of non-melanoma skin cancers of the head and neck. Turkderm - Arch Turk Dermatol Venerology 2016;50:2-9.

33. Patel $R$, Strimling $R$, Doggett $S$, et al: Comparison of electronic brachytherapyand Mohs micrographic surgery for the treatment of earlystage non-melanoma skin cancer: a matched pair cohort study. J Contemp Brachytherapy 2017;9:338-44.

34. Rogers-Vizena CR, Lalonde DH, Menick FJ, Bentz ML: Surgical treatment and reconstruction of nonmelanoma facial skin cancers. Plast Reconstr Surg 2015;135:895e-908e.

35. Chren M-M, Torres JS, Stuart SE, Bertenthal D, Labrador RJ, Boscardin WJ: Recurrence after treatment of nonmelanoma skin cancer: a prospective cohort study. Arch Dermatol 2011;147:540-6.

36. Immerman SC, Scanlon EF, Christ M, Knox KL: Recurrent squamous cell carcinoma of the skin. Cancer 1983;51:1537-40. 